\title{
PRedATORY CONDUCT UNDER THE COMMERCE ACt 1986
}

\author{
David Coull
}

This article examines the significance of the Court of Appeal's decision in Commerce Commission v Port Nelson Limited. The Court's analysis of predatory pricing, "bundling" and the tug tie is explored. The paper concludes that the effect of the Court of Appeal's decision is to significantly widen the scope of section 27 of the Commerce Act. This is contrasted with the restrictive interpretation that recent courts have accorded section 36. The paper concludes that court decisions have fundamentally changed the scheme of the Commerce Act 1986.

\section{INTRODUCTION}

The Commerce Act 1986 ("the Act") is intended to promote competition in New Zealand markets. This purpose is primarily achieved by section 27 and section 36 of the Act. Each section prohibits different types of conduct that reduce competition. Section 27 targets collusive agreements between two or more firms which substantially lessen competition in a market. The focus of the section is therefore on bilateral conduct. Section 36 focuses on a firm which uses its dominant position in a market for one of the proscribed anticompetitive purposes. Section 36 is therefore focused toward preventing unilateral anticompetitive action by a firm with a significant degree of market power.

The previously well accepted distinction between the types of conduct respectively targeted by section 27 and section 36 has been fundamentally changed by Commerce Commission $v$ Port Nelson Limited. ${ }^{1}$ This decision demonstrates that section 27 can now be used to challenge the conduct of a firm that acts unilaterally with the intention of eliminating a competitor from a market. This is particularly significant in two respects. The scope of section 27 has been widened. A greater variety of anticompetitive conduct is now susceptible to challenge using the section. Secondly, the decision changes the underlying scheme of the Act. Section 27, as well as section 36, can now potentially be used to challenge predatory conduct. Whether it is appropriate to dilute the conceptual

* This is an abridged version of a paper submitted as part of the VUW LLB (Honours) programme.

1 [1996] 3 NZLR 554. Gault J delivered the judgment of the Court of Appeal. 
distinction between unilateral and collusive conduct, as was effectively done in Port Nelson, is a question that is considered later in this paper. ${ }^{2}$

Part II outlines the scheme and purpose of the Act. The prohibitions contained in both section 27 and section 36 are outlined, and the interpretation of each section by the courts prior to Port Nelson is summarised. The types of conduct that each section typically seeks to prevent are also considered. Part III analyses how the predatory conduct that occurred in Port Nelson was challenged by the Commerce Commission under section 27 and considers how similar conduct is challenged in overseas jurisdictions. Part IV considers the legal interpretations of section 27 that were adopted by the High Court and the Court of Appeal in Port Nelson. The width of these interpretations is analysed.

Part V considers how section 36 can be used to challenge predatory conduct. Recent court decisions that have narrowed the scope of section 36 are considered and critically analysed. The paper concludes by assessing whether the effectiveness of the Act in challenging predatory conduct has been diminished by these recent decisions. Whether legislative reform is required to remedy any defects in the Act that have emerged is also considered.

\section{THE SCHEME OF THE ACT}

\section{A The Purpose of the Commerce Act}

The long title of the Act provides that the purpose of the Act is "to promote competition in markets within New Zealand." Patterson unequivocally argues that the concept of competition is central to the operation of the Act. He states that: ${ }^{3}$

It is clear that competition is the fundamental concept on which the Act is based, and that the promotion of competition is the single objective of the Act.

This view reflects the thinking of the original framers of the Act. A paper released by the Department of Trade and Industry outlining the scope of the Act acknowledged that

2 See Part VI. The conceptual distinction between unilateral and collusive conduct was considered by I Eagles "Of Ports, Pilots and Predation: New Zealand Courts Reassess some Competition Fundamentals" [1996] 8 ECLR 462.

3 RH Patterson "How the Chicago School Hijacked New Zealand Competition Law and Policy" (1996) 17 NZULR 160, 167. Patterson supports this view by reference to the Department of Trade and Industry's Background Paper to the Commerce Bill (1985). This Commentary states that "[t]he policy implicit in the adoption of the objective of promoting competition is that competition will give rise to durable economic and social outcomes. For example assisting in the achievement of economic efficiency or consumer protection objectives." 
the promotion of competition was the primary policy objective. ${ }^{4}$ A vigorous debate centring on whether the promotion of competition remains the primary focus on the Act has ensued. ${ }^{5}$ The increasing acceptance by the courts of efficiency-based justifications for conduct undertaken in New Zealand markets reflects the increasing influence of "Chicago School" theory on New Zealand's competition law and practice. ${ }^{6}$

The leading statement by the Court of Appeal on the role of the Act emphasises the importance of rivalrous conduct between competitors. The Court of Appeal in Tru Tone Ltd v Festival Records Retail Marketing Ltd stated that: ${ }^{7}$

[the Act] is based on the premise that society's resources are best allocated in a competitive market where rivalry between firms ensures maximum efficiency in the use of resources.

The Act has become an important tool in regulating the competitive conduct of firms that are operating in industries that have recently been deregulated. ${ }^{8}$ Judicial interpretations of the prohibitions contained in the Act must be seen against this background. The principal prohibitions are analysed below.

\section{B Substantial Lessening of Competition}

Section 27 prevents firms from entering a contract, arrangement or understanding which substantially lessens competition in a market. Section 27(1) provides:

27. Contracts, arrangements, or understandings substantially lessening competition prohibited-(1) No person shall enter into a contract or arrangement, or arrive at an understanding, containing a provision that has the purpose, or has or is likely to have the effect, of substantially lessening competition in a market.

Section 27 only applies to contracts, arrangements or understandings. Anticompetitive conduct will often arise out of a contract. Whether a contract exists is determined by the ordinary common law rules and the term does not have a specialised

4 Department of Trade and Industry Commerce Bill 1985-A Background to the Bill and an Outline of its Provisions (Wellington, 1985) 3.

5 The competing views are conveniently summarised in Patterson, above n 3, 166-172.

6 See Fisher \& Paykel v Commerce Commission [1990] 2 NZLR 731, and the criticism of the reliance on Chicago School Theory in R Ahdar "Exclusive Dealing and the Fisher \& Paykel Saga" (1992) 15 NZULR 1.

7 [1988] 2 NZLR 352, 358. This statement was cited with approval in Fisher \& Paykel v Commerce Commission, above $\mathrm{n} 6,756$.

8 J Farmer "Transition from Protected Monopoly to Competition: The New Zealand Experiment" (1993-94) 1 CCLJ 1 contains an interesting analysis of the Act's importance in recently deregulated industries. 
meaning in the Act. $^{9}$ Arrangements and understandings encompass dealings between parties that do not give rise to a binding contract. These concepts require a meeting of minds between two or more people that leads to an agreed course of action. ${ }^{10}$

The section applies to horizontal agreements between competitors designed to exclude another competitor from a market. ${ }^{11}$ It equally applies to vertical agreements between parties at different functional levels in a market that restrict competition. ${ }^{12}$ The premise underlying section 27 is that collusion exists between the parties to the agreement. ${ }^{13}$ This premise can be inferred from the use of the words "contract, arrangement or understanding". These words require a "meeting of minds" between the relevant parties. ${ }^{14}$ In New Zealand Magic Millions Ltd $v$ Wrightson Bloodstock Ltd, Tipping J commented that: ${ }^{15}$

Section 27 is aimed at contracts or understandings between parties having the collusive effect of reducing competition. To bring s 27 into play there must I would have thought be some meeting of minds between the parties to the alleged contract or arrangement or understanding.

Section 27 does not seek to identify and prohibit specific anticompetitive practices. Section 27 only prohibits contracts, arrangements or understandings which have the purpose, effect or likely effect of "substantially lessening competition in a market". The types of conduct that may substantially lessen competition are potentially very broad. Whether a particular type of conduct contravenes section 27 depends upon the nature of the conduct and whether it interferes with the competitive processes that occur within a market. Determining whether competition has been substantially lessened therefore requires the nature of the competition in the market to be considered.

9 See Hughes v Western Australian Cricket Association (1986) ATPR 40-736.

10 British Basic Slag $v$ Registrar of Restrictive Trading Agreements [1963] 2 All ER 807; TPC $v$ Nicholas Enterprises Pty Ltd (1979) ATPR 40-126; Apple Fields Ltd v New Zealand Apple and Pear Marketing Board [1991] 1 NZLR 257 (PC).

11 For example, Re Chemists' Guild of New Zealand (Inc) (1987) 1 NZBLC (Com) 104,058.

12 For example, Fisher \& Paykel, above n 6.

13 The authors of GQ Taparell, RB Vermeesch and DJ Harland Trade Practices and Consumer Protection (3 ed, Butterworths, Sydney, 1983) at paragraph 523 clearly anticipate that collusion is necessary for a contract, arrangement or understanding to exist. A similar conclusion is reached in I Bruce, G Donald, JD Heydon Trade Practices Law: Restrictive Trade Practices, Deceptive Conduct and Consumer Protection (The Law Book Co Ltd, Sydney, 1989) 131.

14 Above $\mathrm{n} 10$. 
The way in which section 27 has recently been applied by the courts to challenge alledgedly anticompetitive conduct indicates that the effectiveness of section 27 was open to question. The decision in Fisher $\mathcal{E}$ Paykel is an example of a situation where section 27 should arguably have applied to prevent the conduct that occurred in that case. The decision in Port Nelson must be seen against this background.

\section{The Use of a Dominant Position}

Section 36 prevents firms that are in a dominant position in a market from using that position for one of the proscribed anticompetitive purposes. ${ }^{16}$ Section $36(1)$ reads:

36. Use of dominant position in a market-(1) No person who has a dominant position in a market shall use that position for the purpose of-

(a) Restricting the entry of any person into that or any other market; or

(b) Preventing or deterring any person from engaging in competitive conduct in that or any other market; or

(c) Eliminating any person from that or any other market.

Section 36 does not prohibit the "creation and continued existence" of dominant firms in New Zealand markets. ${ }^{17}$ Similarly, the Privy Council has observed that section 36 does not prevent dominant firms competing against other firms: ${ }^{18}$

A monopolist is entitled, like everyone else, to compete with its competitors: if it is not permitted to do so it "would be holding an umbrella over inefficient competitors"...

Rather the section targets dominant firms which use their position for one of the proscribed anticompetitive purposes. The misuse by firms of their dominant position is the type of conduct targeted by section 36. The focus is on these firms unilaterally exercising their market power to the detriment of other competitors, or potential competitors, in the market.

Section 36 has three main constituent parts, each of which must be satisfied before a breach of the section can be established. ${ }^{19}$ A firm must be in a dominant position in a

16 The proscribed purposes are detailed in s 36(1)'s three limbs, (a), (b) and (c).

17 See L Hampton "Section 36(1) of the Commerce Act 1986: An Analysis of its Constituent Elements" in RJ Ahdar (ed) Competition Law and Policy in New Zealand (The Law Book Co Ltd, Sydney, 1991) 179.

18 Telecom Corporation of New Zealand Limited v Clear Communications Limited [1995] 1 NZLR 385, 402 (PC).

19 See generally M Berry, T Housden and T M Gault (eds) Gault on Commercial Law (Brookers Ltd, Wellington, 1994). 
market; the firm must use that position; and the use must be for one of the purposes proscribed by the section. While a detailed analysis of each element is outside the scope of this paper, it is necessary to briefly consider each element to fully understand the significance of the decision in Port Nelson. These elements are discussed below.

Section 36 only applies to firms that have market dominance. The Court of Appeal in Telecom Corporation of New Zealand $v$ Commerce Commission ("AMPS A") ${ }^{20}$ held that "dominance" bears its ordinary meaning and that the factors listed in section 3(8) of the Act should be considered when assessing whether a firm is dominant. AMPS A has been criticised for raising the threshold of market power required to a level that was never intended. ${ }^{21}$ Gault J expressly rejected this criticism in Port Nelson. The level of market power required for section 36 is that anticipated by Article 86 of the Treaty of Rome, on which the New Zealand concept of dominance is modelled. ${ }^{22}$ Determining whether this threshold is passed, so that section 36 applies, requires a broad factual assessment of the circumstances. $^{23}$

A firm must "use" its dominance for a proscribed "purpose" before section 36 is contravened. The meaning of "use" was considered by the Privy Council in Telecom Corporation of New Zealand Limited $v$ Clear Communications Limited. ${ }^{24}$ A firm does not use its market dominance if it acts in a way that a non-dominant firm in a contestable market would act. This test has been severely criticised for being too restrictive and therefore limiting the effectiveness of section 36. The Privy Council appears also to have downplayed the importance of proving that the alleged anticompetitive conduct has the necessary proscribed purpose. These elements of section 36 are considered in greater detail in Part V.

20 [1992] 3 NZLR 429.

21 See RH Patterson "The Rise and Fall of a Dominant Position in New Zealand Competition Law: From Economic Concept to Latin Derivation" (1993) 15 NZULR 265.

22 Above n 1, 574. McGechan J's judgment in Port Nelson is also premised on this basis. McGechan J's approach to the question of market dominance was expressly approved in Power New Zealand Ltd $v$ Mercury Energy Ltd [1996] 1 NZLR 686, 710.

23 Above n 1, 573. See, for example, Re Continental Can Co Inc [1972] CMLR D11 and Hoffman-La Roche \& Co v EC Commission [1979] 3 CMLR 211.

24 Above $\mathrm{n}$ 18. The exact wording of the Privy Council's test is quoted in Part V. 


\section{PORT NELSON AND PREDATORY CONDUCT}

\section{A The Nature of the Conduct in Port Nelson}

The decision of the Court of Appeal is the third time that the conduct of Port Nelson Limited ("PNL") has been considered by the courts in relation to alleged breaches of the Act. ${ }^{25}$ This presumably reflects PNL's response to the increased competitive threat that it faced in certain aspects of its operations since the deregulation of port activity throughout New Zealand.

PNL provided port facilities at Nelson. PNL also supplied related services, the most important of which were tug services and pilot services. All vessels entering Port Nelson had to be piloted. PNL initially supplied pilot services to vessels using pilots contracted from Tasman Bay Maritime Pilots Ltd ("TBMPL"). Difficulties in renegotiating these contracts lead to the termination of this relationship. At this point, TBMPL decided to provide independent pilotage services direct to vessels entering Port Nelson. PNL employed one pilot to perform the pilotage services that it offered. The provision of pilotage services was therefore competitive.

PNL was concerned by this competitive threat. PNL responded with three measures. It refused to allow TBMPL to use the tugs that it owned unless any pilotage services required were provided by PNL employees. This was described as a "tug tie". The possibility of competition had caused PNL to separate its charges for pilotage services from its other charges. PNL's pilotage charges were based on the vessel's gross registered tonnage ("GRT"), with the minimum charge being \$100 for vessels up to 2500 GRT. Finally, PNL offered a five per cent discount on all its charges to vessels that used PNL for tug, pilotage and ships lines services and that also used PNL's subsidiary company for any stevedoring that was required. The minimum pilotage charge and five per cent discount were provided for in a contract entered into between PNL and the consumers of services provided by PNL at Port Nelson. These contracts, which were challenged under section 27 , were therefore vertical supply contracts.

The Commerce Commission investigated the measures undertaken by PNL. In due course it commenced a proceeding against PNL alleging breaches of section 27 and section 36 of the Act. The case came before McGechan J and Professor Lattimore in the High Court. ${ }^{26}$ The High Court held that the five per cent discount and the $\$ 100$ minimum

25 The other two occasions where Union Shipping NZ Ltd $v$ Port Nelson Ltd [1990] 2 NZLR 662 and Stevedoring Services (Nelson) Ltd v Port Nelson Ltd [1992] NZAR 5.

26 Professor Lattimore was the lay assessor who sat as a member of the Court pursuant to s 78 of the Act. 
charge breached section 27 and that the tug tie breached section 36 . These decisions were upheld by the Court of Appeal.

\section{B Market Definition}

The Court of Appeal acknowledged that defining the relevant market was difficult where "virtually the whole area of relevant commercial activity is in transition from statutory monopoly and has only recently been opened to competitive conduct." 27

PNL argued that the provision of tug services and pilotage services to shippers that used the port should be viewed as integrated services and was therefore part of a single vessel movements market. The Commerce Commission argued that tug services and pilotage services were often supplied separately, both in Nelson and overseas, and therefore comprised separate markets. McGechan J stated: ${ }^{28}$

Vessels coming from abroad will be familiar with provision of pilotage and towage separately.

It is not outside contemplation [that] pilotage could be taken from one source, and towage from

another. With a price differential, such indeed would be likely.

The Court of Appeal was clearly aware of the significance of this finding for the ultimate outcome of the case when it commented that acceptance of separate tug services and pilotage services markets was of "considerable significance" in assessing PNL's conduct against sections 27 and 36. The Court of Appeal however concurred with the High Court's assessment of the relevant markets.

\section{Predatory Pricing}

The Act does not define or specifically prohibit predatory pricing. ${ }^{29}$ While predatory pricing is a difficult concept to define, it generally describes the situation where a firm reduces the price of goods and services below cost for the purpose of reducing or eliminating competition within a market. ${ }^{30}$ However, this generic description of predatory pricing is imprecise because firms will often reduce the price of goods and

27 Above n 1, 560.

28 Commerce Commission v Port Nelson Ltd (1995) 6 TCLR 406, 520 (HC).

29 Y van Roy "Predatory Pricing and Sections 36 and 36A of the Commerce Act 1986" presented at the First Annual Workshop of the Competition Law and Policy Institute of New Zealand Inc (Christchurch, 1990) 3.

30 V Nagarajan "The Regulation of Predatory Pricing within s 46 of the Trade Practices Act 1974" (1990) 18 ABLR 293, 294 and K McMahon "Predatory Pricing under Section 46 of the Trade Practices Act and the decision in Eastern Express v General Newspapers-Part I" (1993) 1 TPLJ 75, 76. The Australian courts have generally declined to attempt exhaustive definitions of what constitutes "predatory pricing". 
services to very low levels for legitimate commercial reasons. The difficulty that the courts face is determining whether, in light of the surrounding circumstances, a firm can properly be seen as engaging in predatory pricing or is simply engaging in vigorous competitive activity. This distinction is often difficult to draw.

Whether "predatory pricing" can be challenged under either section 27 or section 36 therefore depends on the nature of the conduct that is proscribed by each section. The statutory requirements, rather than generic definitions of predatory pricing, determine whether "predatory" price reductions are prohibited in New Zealand. The application of each section to the circumstances of each case must therefore be the central inquiry. This Part considers how section 27 and section 36 can be used to challenge predatory pricing and whether one section should be preferred to the other in any given set of circumstances.

\section{The approach to predatory pricing in Port Nelson.}

Section 36 has traditionally been the most likely avenue to use when challenging predatory pricing. This view has substantial academic support, ${ }^{31}$ even though predatory pricing has not yet been successfully challenged under section 36. The probable reason for this prevailing view is that the Australian courts had analysed allegations of predatory pricing under the Australian equivalent to section 36 in the Australian Trade Practices Act 1974 (the "ATPA"). The combination of market power and behaviour required to successfully engage in predatory pricing seems to indicate that section 36 is "directed" toward prohibiting conduct of this kind. Predation, by its nature, requires a high degree of market power. The more market power a firm has, the more likely it is that that firm will be able to successfully engage in predatory pricing. A participant in a highly competitive market is unlikely to have the ability to successfully eliminate a competitor by pricing below cost.

Some commentators have taken the view that conduct that is considered to be "predatory pricing" may not contravene section $36 .{ }^{32}$ Section 36 cannot be used to challenge the pricing decisions of firms that do not have market dominance. Nor can section 36 be relied upon where the firm does not "use" its dominant position. Port

31 See Y van Roy, above n 29; Y van Roy Guidebook to New Zealand Competition Laws (2 ed, CCH New Zealand Ltd, Auckland, 1991) 760; Gault on Commercial Law, above n 19, CA 36.20; J Eisenberg "Predatory Pricing in the Context of Australian and New Zealand Competition Law" in Commerce Commission Current Issues in New Zealand Competition and Consumer Law (Wellington, volume 4, 1991); K McMahon "Predatory Pricing under Section 46 of the Trade Practices Act and the decision in Eastern Express v General Newspapers-Part II" (1993) 1 TPLJ 130.

32 Above n 29, 3. 
Nelson demonstrates that below cost pricing can also be successfully challenged under section 27 of the Act.

The nature of the $\$ 100$ minimum charge for pilot services was considered by the High Court. The amount charged by PNL for pilot services depended on the weight of the piloted vessel. This charge increased with the weight of the vessel. However, PNL imposed a minimum charge of $\$ 100$ for any pilotage services that it provided. The minimum charge primarily affected vessels that operated in the "smaller vessel end of the market". ${ }^{33}$ The Commerce Commission alleged that a minimum charge which operated in this way breached section 27 of the Act. The High Court held that the \$100 minimum charge for pilotage services breached section 27 because it had the purpose and likely effect of substantially lessening competition in the pilotage market. This finding was upheld by the Court of Appeal.

The approach of both the High Court and Court of Appeal to the $\$ 100$ minimum charge is noteworthy. Although both Courts relied on overseas authorities which have analysed predatory pricing, they did not attempt to define predatory pricing or to determine the kinds of pricing policies that may or may not amount to predatory pricing. This indicates the reluctance of the New Zealand courts to enter into the definitional debates that have surrounded predatory pricing in the United States. These definitional issues should not distract the Court from the inquiry mandated by the Act. Accordingly, the Court of Appeal commented that "[i]t is preferable to concentrate on the terms of the statute." 34 In the High Court, McGechan J observed that section 27 would be satisfied if: ${ }^{35}$

the activity has the features of pricing below cost, with associated substantial purpose of eliminating or deterring present competition, and the creation of a deterrent aggressive reputation.

McGechan J therefore considered two issues. First, whether the price charged was below the cost of providing the good or service. Secondly, whether the purpose, effect or likely effect of the $\$ 100$ minimum charge was to substantially lessen competition in the pilotage market.

33 This term was used by the Court of Appeal to describe the sector of the pilotage market where the piloted vessels weighed less than 2500 GRT. This is the sector of the market where the effect of the minimum price was the most significant.

34 Above n 1, 569. See also the comments of MeGechan J in the High Court, above n 28, 538.

35 Above n 28, 538. McGechan J had already held that the necessary "contract" existed. 
(a) Below cost pricing

The Commerce Commission alleged that the $\$ 100$ minimum charge was substantially below the cost of providing pilotage services and was therefore predatory in nature. McGechan J held that the cost of providing pilots for vessels less than 2500 GRT was "substantially above" the $\$ 100$ minimum charge. ${ }^{36}$ This result followed irrespective of the method used by McGechan J to determine the "cost". ${ }^{37}$ PNL did not seek to challenge this finding on appeal. Port Nelson therefore does not decide how cost should be calculated for determining whether section 27 has been breached.

\section{(b) Purpose, effect or likely effect of substantially lessening competition}

The second requirement necessary to establish a breach of section 27 was that the $\$ 100$ minimum charge must have the purpose, effect or likely effect of substantially lessening competition. This element will often be difficult to satisfy where the conduct that is alleged to substantially lessen competition is a price reduction. The Court of Appeal recognised that price reductions generally reflect competition at work and that therefore below cost pricing "will not frequently give rise to competition law concerns". ${ }^{38}$

Where a firm reduces its price below cost, the reduction can be viewed in two ways. Either the reduction reflects vigorous competition in a marketplace, or it can be seen as an exclusionary measure designed to reduce competition in the marketplace in the long term. The Court of Appeal recognised this distinction when it said: ${ }^{39}$

It is not a contravention of s 27 to offer or sell goods or services at less than cost. The section requires proof of the substantial lessening of competition - not merely aggressive competitive conduct. The purpose or (likely) effect must be more than short-term and must impact upon the competitive process in the particular market structure. The mere fact that a participant operates in the market at a loss, and even fails, will not necessarily lessen competition.

This is a significant statement as to how below cost pricing will be treated under section 27. How the price reduction impacts on the competitive process in the market will determine whether section 27 applies. It is therefore necessary to consider the

36 This is the smaller vessel end of the market.

37 McGechan J identified a number of different ways to calculate the cost of providing pilotage services. His Honour did not decide which was the most appropriate basis to use to calculate the cost as the $\$ 100$ minimum charge was below all the measures of cost that he identified.

38 Above $\mathrm{n}$ 1, 572. The Court of Appeal cited Brooke Group Ltd v Brown \& Williamson Tobacco Corp 113 S Ct 2578 (1993) in support of this proposition.

39 Above n 1, 571. 
circumstances that led McGechan J and the Court of Appeal to conclude that the $\$ 100$ minimum charge breached section 27 of the Act.

The Court of Appeal recognised that the purpose or likely effect of below cost pricing had to be more than short-term to contravene section 27.40 This accords with the use of the word "substantial" when determining whether competition has been substantially lessened.

The Court of Appeal was faced with the argument that the purpose or likely effect of the price reductions could not be to substantially lessen competition unless the firm could recoup lost profits by increasing its price once its competition was eliminated. This argument was rejected by the Court because, in the circumstances of the case, it ignored PNL's ability to cross-subsidise any loss made in the smaller vessel end of the pilotage market from profits made on non-contestable services. These non-contestable services included pilotage services in the larger vessel end of the market where PNL did not face any competition. ${ }^{41}$ Port Nelson therefore establishes that while the ability to recoup losses may indicate the anticompetitive purpose or effect of below cost pricing, it is not essential to establish a breach of section $27^{42}$

The reasoning of McGechan J and the Court of Appeal demonstrates the importance of the tug tie's existence in reaching the conclusion that the minimum charge breached section 27. The tug tie effectively prevented PNL's competitors from entering the larger vessel end of the pilotage market without first entering the tug market. The Court of Appeal reasoned that: ${ }^{43}$

because of the effect of the tug tie and the discount (the larger the vessel the greater the available discount) upon the existing competitor and potential entrants in the pilotage market effectively confining them to the smaller vessel end of the market - the below cost charge by PNL for pilotage must be seen as exclusionary... .

PNL's expectation in imposing the minimum charge and tug tie was that few pilotage tasks would have been available to TBMPL in circumstances where PNL's minimum charge would not apply. ${ }^{44}$ The necessary conclusion reached by the Court of Appeal was that the below cost pilotage charge was likely to substantially lessen competition.

40 Above n 1, 571.

41 The reason why PNL did not face any competition in this sector of the market was because of the tug tie.

42 Above $\mathrm{n} 1,571$.

43 Above $\mathrm{n} 1,572$.

44 Above n 1, 570. 
This conclusion should not be seen to imply that every instance of below cost pricing will breach section 27. The Court of Appeal acknowledged that in some circumstances below cost pricing and minimum charges are no more than aggressive competitive conduct. McGechan J also recognised that minimum charges have an "accepted commercial purpose."45 However, McGechan J did observe that the "commercial community would look askance at a minimum charge outrageously below [the] actual cost of the services concerned, asking the longer term reason for such deliberate loss taking." 46 Whether below cost pricing contravenes section 27 will accordingly depend upon the purpose and effect of the price reductions being considered by the court.

\section{How should predatory pricing be challenged?}

Predatory pricing can now be challenged using both section 27 and section 36. Port Nelson and Eastern Express establish that the courts are likely to focus on the respective statutory requirements to determine whether the pricing policies complained of breach either section. The structure of the market and the circumstances surrounding the price reductions are therefore important considerations.

The concepts analysed by McGechan J and the Court of Appeal in Port Nelson were developed by United States and Australian courts in the context of each jurisdiction's equivalent to section 36 of the Act. The Court of Appeal in particular considered how these concepts apply in the context of section 27. Two factors that are influential in these overseas jurisdictions are not required under section 27.

Australian courts have held that predatory pricing will contravene section 46 of the ATPA where the price reductions are temporary in nature, as this allows the court to infer a predatory purpose. ${ }^{47}$ There was no indication in Port Nelson that the minimum charge was temporary and would be removed when PNL's competitor was eliminated for the pilotage market. ${ }^{48}$ Secondly, the Court of Appeal held that a firm did not necessarily have to be able to recoup any short term losses incurred while eliminating its competition. ${ }^{49}$ This is inconsistent with the approach of the United States Supreme Court which requires a firm to recoup these losses to successfully challenge predatory pricing.

45 Above n 28, 539

46

Above n 28, 539.

47 The Victorian Egg Marketing Board v Parkwood Eggs Pty Ltd (1978) ATPR 40-081.

48 The argument that the minimum charge was not a sporadic or temporary measure was advanced by PNL before the High Court. See above n 28, 532 .

49 Courts in overseas jurisdictions have generally required a firm to be able to recoup any profits temporarily forgone once targeted competitors have been eliminated from the market. In the United States, see Brooke Group Ltd v Brown \& Williamson Tobacco Corp, above n 38, where it seems 
The background of animosity between PNL and TBMPL and the fact that the minimum charge was used in conjunction with the tug tie and the discount provided the basis for McGechan J's finding that the purpose and likely effect of the minimum charge was to substantially lessen competition in the pilotage market. This combination of factors may not be present in future litigation where predatory pricing is alleged. The precise requirements necessary to establish that future instances of below cost pricing breach section 27 are therefore not clear.

The Court of Appeal in Port Nelson did not clarify what is required to infer an anticompetitive purpose for section 36. It is however likely that the same approach to determining the purpose or likely effect of below cost pricing for section 27 will be used to determine a firm's purpose for section 36. The result should normally, although not always, be the same. Whether section 27, section 36, or both are used to challenge predatory pricing will therefore often depend on whether a litigant can satisfy the other elements of the section. Recent decisions concerning section 36, including Port Nelson, indicate that the requirements of section 27 may be easier to satisfy in any given situation.

\section{Discounts Given For Bundled Goods and Services}

Where a customer purchases more than one good or service from the same supplier, that supplier will commonly discount the price that would ordinarily be charged. The amount of the discount will often increase as more goods or services are purchased from this supplier. The use of discounts in these circumstances is common commercial practice.

A discount of this nature was used by PNL in Port Nelson. PNL offered a discount on "all of the Port Company's charges" if "all services required" by the vessel were provided by PNL and any stevedoring services required by the vessel were provided by a stevedore who "uses PNL employees". The service contract defined "all services required" as tugs, pilotage and ship lines. These were the services where it was possible for TBMPL, if it so chose, to compete with PNL. McGechan J characterised these services as the "contestable" services. However, the discount also applied to incontestable services including port access, berthage, equipment and wharfage. TBMPL could not compete in these areas because of PNL's natural monopoly.

McGechan J and the Court of Appeal held that a discount structured in this way substantially lessened competition and therefore breached section 27 of the Act. The objectionable aspect of the discount was that it applied across both contestable and

that assessing a firm's ability to recoup losses has replaced the cost-based tests as an indicator of predatory pricing. For analysis of the Australian position, see G A Hay and K McMahon Predatory Pricing in an Oligopoly Context (1995) 3 CCLJ 144. 
incontestable services. Even if TBMPL could supply contestable services more efficiently than PNL, a customer would be likely to purchase contestable services from PNL in order to obtain the benefit of the discount that applied to the incontestable services. In order to be able to effectively compete, any discount that TBMPL offered would have to exceed the combined discount offered by PNL across both contestable and incontestable services.

This effect was more severe because the incontestable services were essential services. All vessels entering the port had no alternative but to use the port services offered by PNL. The effect of a discount structured in this way is that the monopoly supplier of incontestable services will eventually achieve a monopoly in the supply of contestable services. McGechan J concluded: ${ }^{50}$

[I]t is clear the grant by a monopolist of discount across both monopoly and contestable lines, conditional upon all lines being taken, could in some factual situations have anticompetitive effect. The question cannot be resolved by simple rules of thumb. All will depend on factual variables.

McGechan J then considered why PNL had extended the discount policy to contestable services. ${ }^{51}$ One purpose of the discount identified by McGechan J was to eliminate TBMPL and to send a "warning signal" to potential competitors. The discount effectively required PNL's competitors to reduce the price they charged for contestable services to a level that would match the total price charged for PNL's contestable and incontestable services. However, this was not the only reason. PNL sought to justify the use of the discount on the basis of commonly adopted commercial practices. Extending the discount to contestable services acted as a further incentive for shippers to use PNL's stevedoring labour. The discount also acted as an incentive for shippers to use the contestable services offered by PNL. This can be seen as a legitimate response to the competition that PNL faced in the pilotage market and to a lesser degree, the tug market.

McGechan J held that section 27 applied because a real and substantial purpose of the discount was to eliminate TBMPL and thereby substantially lessen competition in the pilotage market. His Honour reached this conclusion for a number of reasons. PNL perceived TBMPL to be an "acute competitive threat". ${ }^{52}$ This perception led to a corresponding desire to restrict or eliminate TBMPL from the pilotage market. McGechan J further held that there would have been a belief that a discount offered

50 Above n 28, 524 .

51 The discount was initially offered across incontestable services with the intention of maintaining the use of PNL's stevedoring labour. See above n 28, 525 and generally Union Shipping NZ Ltd $v$ Port Nelson Ltd, above n 25.

52 Above n 28, 525 . 
across all services supplied by PNL would have been severely detrimental to TBMPL. He concluded: ${ }^{53}$

Except for small vessels, with short stays, which would incur relatively lower PNL charges and for which the discount would be correspondingly lower, the discount would be well nigh unmatchable by TBMPL.

Therefore the structure of the discount and the animosity between PNL and TBMPL allowed McGechan $\mathrm{J}$ to find that the purpose of the discount was to eliminate TBMPL from the pilotage market and to deter other competitors. McGechan J's finding was affirmed by the Court of Appeal. The Court stated that PNL's awareness of the competitive threat and its determination to resist this threat were demonstrated by the tug tie.

McGechan J also found that the likely effect, although not the actual effect, of the five per cent discount was to substantially lessen competition in the pilotage market. The likely effect of discount would be to devastate TBMPL, especially when considered in light of the tug tie and $\$ 100$ minimum charge. ${ }^{54}$ That this did not occur was, in McGechan J's view, unexpected. The Court of Appeal did not consider McGechan J's findings concerning the actual and likely effect of the discount to be inconsistent. ${ }^{55}$

Both McGechan J and the Court of Appeal were influenced by the combined effect of the conduct undertaken by PNL when assessing the likely effect of the five per cent discount on the pilotage market. Whether the same result would have been reached had the five per cent discount been the only form of predatory conduct used by PNL is unclear. Port Nelson provides the basis for the argument that offering discounts for bundled services will, in some circumstances, breach section 27.

\section{THE WIDTH OF SECTION 27 AFTER PORT NELSON}

The decision in Port Nelson has widened the scope of section 27. This Part considers how the High Court and the Court of Appeal interpreted certain aspects of section 27 and whether these interpretations are consistent with the purpose of the section.

\section{A The "Purpose" Limb of Section 27}

Section 27 commonly applies to horizontal agreements that are entered into between competitors for the purpose of substantially lessening competition. The parties to these

\footnotetext{
53 Above n 28, 528 .

54 Above n 28, 530-531.

55 See Part IV.
} 
agreements share the same anticompetitive purpose because they collude in order to secure the commitment of the other parties to an agreed course of action.

This typical situation can be contrasted with the situation in Port Nelson. The potentially anticompetitive provisions were contained in the contract for services to be provided by PNL to its customers. The High Court held that PNL's "real and substantial" purpose in entering into these contracts was to substantially lessen competition in the pilotage market. The counterparty to these contracts, the customer, may have been aware of PNL's purpose, but did not share the same purpose. The element of collusion that is often present in horizontal anticompetitive agreements did not exist between PNL and its customers. The question to be decided by the High Court and the Court of Appeal in Port Nelson was whether section 27 would apply where the anticompetitive purpose was held by only one of the parties to the contract.

The Court of Appeal, relying on both New Zealand and Australian authorities, held that it was sufficient if only one of the parties to the contract had an anticompetitive purpose. Gault J expressed concern that if the Court required the purpose of the contract to be shared by all parties, the effectiveness of section 27 would be considerably limited. He said: ${ }^{56}$

The objective of the statutory provision must also be borne in mind. The promotion of competition should not be inhibited by the artificiality of search for unanimous purposes.

Gault J supported this decision by reference to Tui Foods Ltd $v$ New Zealand Milk Corporation Ltd. ${ }^{57}$ This case concerned the application of section 29 of the Act to an allegedly exclusionary contract. Cooke $\mathrm{P}$ held that if only one party is responsible for including an anticompetitive clause in a contract, then that person's anticompetitive purpose is sufficient to establish a breach of section 29. Once a contract is concluded then all parties must be taken to share the purpose of its provisions. ${ }^{58}$ Gault J expressly stated that this reasoning was equally applicable to section $27^{59}$

Hampton is critical of the Court of Appeal's decision in Port Nelson. He argues that the Court of Appeal's approach is "conceptually unsound and fails to take into account

56 Above $\mathrm{n} 1,564$.

57 (1993) 5 TCLR 406 (CA).

58 Cooke P's interpretation of s 2(5)(a) formed the basis of this conclusion.

59 The Court of Appeal's reliance on s 2(5)(a) has been criticised in LF Hampton "Port Nelson Ltd v Commerce Commission: Has the Court of Appeal read the need for concerted action out of s 27 of the Commerce Act?" presented at the Eighth Annual Workshop of the Competition Law and Policy Institute of New Zealand Inc (Auckland, 1996). Hampton argues that s 2(5)(a) is not relevant to determining whether "purpose" in s 27 requires unilateral or common purpose. 
the genesis of s 27 " by focusing on the purpose of the party responsible for including the anticompetitive provision in the contract. ${ }^{60}$ This argument is based on United States case law which has interpreted section 1 of the Sherman Act 1890. This section, which is broadly similar to section 27, requires concerted action between two or more firms to achieve an anticompetitive objective. ${ }^{61}$ Where a horizontal agreement between competitors is being challenged, the agreement breaches the Sherman Act where the conspirators have a "unity of purpose or a common design and understanding, or a meeting of minds in an unlawful arrangement". ${ }^{62}$ Unity of purpose is unlikely to be present in many vertical agreements because the parties entering into the agreement are likely to have different purposes for doing so. This does not however mean that anticompetitive vertical agreements escape condemnation under the Sherman Act. These agreements are illegal where the parties show "a conscious commitment to a common scheme designed to achieve an unlawful objective". ${ }^{63}$ This commitment may be voluntary or secured by coercion.

Hampton advocates an approach that is more conceptually correct than the approach adopted in Port Nelson. However, the reasoning in Port Nelson would be different had Hampton's approach been adopted. Because only PNL would have been committed to eliminating its competitors from the pilotage market, the purpose limb of section 27 would not have been satisfied. The Commerce Commission would therefore have to have challenged PNL's conduct using the "effect" or "likely effect" limbs of section 27, or section 36 .

A litigant need only show that one party to the contract has an anticompetitive purpose. This is not of such significance where the allegedly anticompetitive contract is entered into between competitors, as, generally speaking, all the parties to this type of contract will share the same purpose. Section 27 has clearly always applied to these kinds of contracts. ${ }^{64}$ The finding is however significant in the context of anticompetitive agreements that are not made between competitors. The contracts for the supply of services that were at issue in Port Nelson provide a good example. Where one party includes an anticompetitive clause in a standard form supply contract, which the

60 Above n 59, 1

61 See above $\mathrm{n} 59,2-3$.

62 American Tobacco Co v United States 328 US 781, 783 (1946).

63 Monsanto Co v Spray-Rite Service Corp 465 US 752, 763 (1963).

64 An example is Re Chemists' Guild of New Zealand (Inc) (1987) 1 NZBLC (Com) 104,058. 
counterparty may not even be aware of, all parties to that contract are potentially liable for any breach of section $27 .^{65}$

The question raised by the Court of Appeal's adoption of a unilateral purpose test is whether section 27 should be available to challenge the conduct of a party who does not have an anticompetitive purpose. It is difficult to imagine that Parliament could have intended that a customer who purchases goods or services from a supplier who is using that supply contract to eliminate a competitor from the market would breach the Act. There should, in principle, be no objection to a customer who uses the prevailing market conditions to achieve the best bargain that he or she can. Merely taking advantage of such contractual conditions does not mean that the customer who purchases the services should be attributed the purpose of excluding a participant from the relevant market. ${ }^{66}$ Such an approach does not conform with commercial reality.

\section{B Substantial Lessening of Competition in the Pilotage Market}

\section{The "effect" and the "likely effect" limbs of section 27}

McGechan J held that for conduct to have the effect of substantially lessening competition, that conduct must cause a lessening of competition that is "more than insubstantial or nominal". ${ }^{67}$ This interpretation was clearly supported by the relevant authorities. ${ }^{68}$ McGechan J however held that neither the five per cent discount nor the $\$ 100$ minimum charge had the effect of substantially lessening competition. The reason given for this finding was that despite PNL's clear efforts, these measures had not succeeded in eliminating TBMPL from the pilotage market.

The Commerce Commission appealed against McGechan J's finding that the five per cent discount did not substantially lessen competition. After recognising that "[c]ompetition had emerged [in the pilotage market] but subject to continued hindrance", the Court of Appeal continued: ${ }^{69}$

65 The Court of Appeal acknowledged that on this interpretation a party may contravene s 27 in ignorance. This concern was not considered significant. See above n 1, 564.

66 Carlton and United Breweries (NSW) Pty Ltd v Bond Brewing New South Wales Ltd (1987) ATPR 40820, 48,880. See also A Borrowdale (ed) Butterworths Commercial Law in New Zealand (3 ed, Wellington, Butterworths, 1996) 653.

67 Above n 28, 434.

68 Tillmans Butcheries Pty Ltd v Australasian Meat Industry Employees' Union (1979) 27 ALR 367; Mobil Oil Corp $v$ The Queen in Right of New Zealand (unreported, 4 May 1989, International Center for Settlement of Investment Disputes, Washington DC, International Arbitral Tribunal Case ARB/87/2); Fisher \& Paykel v Commerce Commission [1990] 2 NZLR 731.

69 Above n 1, 566. 
Of course in practical situations workable and effective competition in a market may develop in the face of anti-competitive conduct and the point will be reached where that conduct no longer can be said substantially to lessen competition. We are handicapped at the appellate level in making any assessment as to whether that point was reached at Port Nelson in the pilot services market and when.

The Court of Appeal appeared to disagree with McGechan J's reasoning concerning the actual effect of the five per cent discount. ${ }^{70}$ Despite these indications, the Court of Appeal did not overrule McGechan J's finding on the basis that it would make no practical difference to the outcome of the case. This implicit criticism appears wholly justified. The combined effect of the five per cent discount and the tug tie on TBMPL would have been severe. TBMPL could not compete in the upper pilotage market, which comprised a significant portion of the overall pilotage market. Competition must have been hindered by these measures, even though TBMPL had managed to survive. McGechan J's conclusion that a "substantial" lessening of competition had not occurred seems open to argument. ${ }^{71}$

McGechan J and the Court of Appeal also held that the likely effect of both the five per cent discount and the minimum charge was to substantially lessen competition. McGechan J acknowledged the Australian Federal Court's comments in Tillmans Butcheries Pty Ltd $v$ Australasian Meat Industry Employees' Union ${ }^{72}$ concerning the advantages inherent in retrospectively assessing the likely effect of the conduct. In Tillmans, Deane J commented that: ${ }^{73}$

if conduct had run its ordinary course and had not had the specified effect, it would be but rarely that a court would feel justified in disregarding the lesson of the event and finding that while the conduct did not have the specified effect it had been more likely than not that it would have that effect.

70 The Court of Appeal impliedly disapproved of both the reasons given by McGechan J for finding that the five per cent discount breached s 27. Gault J said (at 566): "The discount, because of it structure, affected competition in the pilotage market. Also, because of its structure, it affected competition in the tug market. That a particular competitor has secured business in the pilotage market by subjecting itself to the impact of the discount also in the tug market seems an unconvincing reason for concluding that the impact no longer exists in the pilotage market. Nor should the temporary presence of artificial constraints bear upon the issue."

71 An argument can be made that a "substantial" lessening of competition can occur notwithstanding the fact that TBMPL was not actually eliminated from the pilotage market. If accepted, this view would mean that the actual effect limb of s 27 was also satisfied.

72 Above $\mathrm{n} 68$

73 Above n 68, 381-382. 
McGechan J thought that the circumstances in Port Nelson justified departing from the approach adopted in Tillmans. His Honour justified this decision on the basis that TBMPL's continued survival was probably attributable to the "freezing" effect of the Commerce Commission's ongoing investigation and the subsequent litigation. ${ }^{74}$

Although McGechan J's finding concerning likely effects may seem unusual in light of his earlier findings in relation to the actual effect of the conduct, there is no reason why this is necessarily so. In this regard, the Court of Appeal commented that: ${ }^{75}$

the decision that the actual effect was not a substantial lessening of competition in the pilotage market is neither inconsistent with, nor undermines, the decision that that was a likely effect when it was introduced.

In light of the rather unique circumstances in Port Nelson, it is unlikely that such a result will occur frequently. The significance of this aspect of the judgment should not therefore be over-estimated.

\section{Elimination of One Competitor}

The courts generally look toward the effect of the conduct on the level of competition in the market rather than its effect on individual competitors in the market to determine whether competition has been substantially lessened. ${ }^{76}$ This distinction was recognised by the Court of Appeal in Port Nelson in the following terms: ${ }^{77}$

The relevant inquiry is as to substantially lessening competition. That is not the same as substantially lessening the effectiveness of a particular competitor. Competition in a market is

a much broader concept. It is defined in s 3(1) as meaning "workable and effective competition". That encompasses a market framework which participants may enter and in which they may engage in rivalrous behaviour with the expectation of deriving advantage from greater efficiency.

The decision in Port Nelson is significant because it demonstrates that predatory conduct directed at one competitor can itself substantially lessen competition. McGechan $\mathrm{J}$ held that the purpose and likely effect of both the discount and the minimum charge was to eliminate TBMPL from the pilotage market and to deter potential competitors from entering the market, thereby substantially lessening competition in the market.

74 Above n 28, 542

75 Above n 1, 567.

76 Gault on Commercial Law, above n 19, CA 27.15; Fisher \& Paykel, above n 68.

77 Above n 1, 564-565. 
PNL challenged McGechan J's findings on the basis that he focused on the likely effect on TBMPL of the discount and the minimum charge, rather than on the likely effect on the level of competition in the market. The Court of Appeal rejected this argument because the distinction between lessening competition and lessening the effectiveness of a particular competitor was not relevant where no other competitors were in, nor seeking to enter, the pilotage market. ${ }^{78}$ Because PNL only faced competition from TBMPL, the elimination of TBMPL from the pilotage market would almost inevitably result in the level of competitive activity undertaken in that market being lessened. The Court of Appeal's reasoning can usefully be compared with how the Australian courts have analysed conduct that is directed at a particular competitor.

The Australian courts have also recognised that the competition test is concerned with the level of rivalrous behaviour in the market and not with the fate of individual competitors. ${ }^{79}$ Corones has however identified two situations where conduct directed at an individual competitor can substantially lessen competition. ${ }^{80}$ These situations are broadly similar to those identified in Port Nelson. The first is where a particularly significant competitor is eliminated from a market. ${ }^{81}$ A likely consequence of such a firm being eliminated from a market would be a reduction in the level of competitive activity in that market. Section 45 of the ATPA may potentially apply in this situation. The second situation is where one firm's elimination operates to intimidate other competitors in the market. Intimidation of this nature may substantially lessen competition in a market because the remaining firms may feel constrained to compete in a certain way in the future. Corones' analysis demonstrates that the approach adopted by McGechan J and affirmed by the Court of Appeal in Port Nelson broadly accords with Australian case law.

Whether conduct directed at a particular competitor will breach section 27 will depend on the surrounding circumstances. Just because a firm's purpose is to eliminate a competitor or to prevent a competitor from competing does not necessarily mean that competition in the market has been substantially lessened. Union Shipping NZ Ltd $v$ Port

78 Above n 1, 565.

79 Outboard Marine Australia Pty Ltd v Hecar Investments (No 6) Pty Ltd (1982) ATPR 40-327; see also SG Corones Competition Law and Policy in Australia (The Law Book Co Ltd, Sydney, 1994) 108.

80 Above n 79, 108-110.

81 This point was recognised in Dandy Power Equipment Pty Ltd v Mercury Marine Pty Ltd (1982) ATPR 40-315, 43,898 and Mark Lyons Pty Ltd v Bursill Sportsgear Pty Ltd (1987) ATPR 40-809. Although these cases focus on s 47 of the ATPA which seeks to prohibit exclusive dealing, the Court's analysis of the kinds of conduct that can amount to a substantial lessening of competition is however equally applicable to s 27 of the Act. 
Nelson $L t d^{82}$ illustrates this point. PNL sought to require a stevedoring company ("USSL") to enter into a contract requiring USSL to only use PNL equipment or to pay a "wharf user levy". ${ }^{83}$ The Court held that this requirement breached section 36(1)(b) of the Act because its purpose was to prevent or deter competitive conduct by USSL ${ }^{84}$

The Court then considered whether this contract, if it had been entered into, would breach section $27^{85}$ Even though USSL controlled $90 \%$ of the Nelson stevedoring market, the Court held that PNL's action to prevent USSL competing in that market would not breach section 27. Such a detriment to USSL did not necessarily substantially lessen competition in the stevedoring market. Rather, the Court recognised that competition may be enhanced ${ }^{86}$

A loss by USSL of some competitive edge (should such occur) might be balanced by competition in the market overall through enhanced opportunity for entry and competitive operation by other operators.

The evidence therefore did not establish that the contract would substantially lessen competition in the market as a whole. Union Shipping shows the importance of looking past the effect of a contractual restriction on an individual competitor and assessing its effect on competition in the relevant market. Section 27 will often be contravened where a significant competitor is prevented from competing in, or eliminated from, a market. However, this result will not always follow. A firm's conduct will not necessarily contravene section 27 just because it contravenes section 36 . Because the inquiry required by section 27 centres on competition in a market, it is broader than the inquiry required by section 36. The effect on the market, rather than just one competitor, must be considered.

Port Nelson demonstrates that predatory conduct directed at another significant competitor or potential competitor in a market may substantially lessen competition. This result is consistent with preceding decisions and does not represent a significant extension of section 27 .

82 Above $\mathrm{n} 25$.

83 Above n 25, 713 .

84 USSL had been found to be dominant in the stevedoring market and seeking to impose restrictive contractual terms was found to be a use of that dominant position.

85 USSL alleged that by attempting to induce it to enter this contract, PNL breached s 82(1)(c) of the Act. Section 27 itself could not be contravened because the relevant contract was not actually entered into.

86 Above n 25, 715 . 
Part IV demonstrated that the Court of Appeal applied section 27 expansively in Port Nelson. Section 27 can accordingly be used to challenge different types of predatory conduct in the future. This can be contrasted with the restrictive interpretation that recent courts have given to section 36. Although a comprehensive analysis of section 36 is outside the scope of this paper, it is necessary to consider the implications of the courts' narrow interpretation of section 36 in the context of predatory conduct.

\section{A A Narrower Interpretation of Section 36}

The elements that must be proved to establish a breach of section 36 were briefly summarised in Part II of this paper. To establish that a particular kind of predatory conduct breaches section 36, it is necessary to satisfy each of these elements. Predatory conduct undertaken by a firm which is not dominant in a market cannot be challenged using section 36. The firm must also have used its dominance for one of the purposes proscribed by section 36 . While all the elements of section 36 must be satisfied, the "use" element will be the most difficult to satisfy where section 36 is used to challenge predatory conduct. This difficulty stems largely from the Privy Council decision in Telecom Corporation of New Zealand $v$ Clear Communications Ltd. ${ }^{87}$

The dispute in Telecom $v$ Clear focused on the amount which Telecom should charge Clear for allowing Clear to interconnect with its national telephone network. The central issue was whether the "Baumol-Willig" rule proposed by Telecom to determine the appropriate price for interconnection to its network breached section 36.88 The Privy Council held that Telecom had not used its dominant position in the national telephone market for one of the proscribed purposes. This result followed from the narrow interpretation given to the "use" element of section $36^{89}$ Lord Browne-Wilkinson stated the test for determining whether the "use" element existed as follows: ${ }^{90}$

\section{[1995] 1 NZLR 385, 402 (PC).}

88 Telecom has monopoly control over the local telephone network, the PSTN. Telecom did not dispute that Clear should be allowed access to that network, but did dispute the terms and cost of access. The Baumol-Willig rule was a pricing rule relied upon by Telecom during the litigation. In essence, the Baumol-Willig rule allowed Telecom to charge Clear its opportunity cost for allowing it access to the PSTN. The major criticism of the rule by the Court of Appeal was that it allowed Telecom to charge Clear monopoly rents.

89 See further Y van Roy "The Privy Council decision in Telecom $v$ Clear: Narrowing the application of s 36 of the Commerce Act 1986" [1995] NZLJ 54, 55.

90 Above n 87, 403. 
it cannot be said that a person in a dominant market position "uses" that position for the purposes of $\mathrm{s} 36$ [if] he acts in a way which a person not in a dominant position but otherwise in the same circumstances would have acted.

Applying this test, the Privy Council held that a hypothetical firm in a fully contestable market would use the Baumol-Willig rule to determine the price that it would charge for supplying a component of a service to a competitor ${ }^{91}$ Telecom therefore could not be said to have "used" its dominant position in the relevant market.

The Privy Council further held that Telecom's reliance on the Baumol-Willig rule meant that it had the purpose of deterring competition. However, the Privy Council's decision concerning the "use" element of section 36 was the crucial finding that determined the outcome of the case. ${ }^{92}$ The importance of establishing the "use" element in future cases is illustrated by Lord Browne-Wilkinson when he said: ${ }^{93}$

If a person has used his dominant position it is hard to imagine a case in which he would have done so otherwise than for the purpose of producing an anti-competitive effect; there will be no need to use the dominant position in the process of ordinary competition.

This is a major change from the approach previously adopted by the courts, which tended to focus on the "purpose" element of section 36. The Privy Council's decision fundamentally changes how section 36 is likely to apply in the future.

\section{B Critique of the Privy Council's Test}

The test for the "use" element has already been subject to some academic criticism. ${ }^{94}$ One of the main criticisms of the decision is that it removes the flexibility that the courts previously had to adopt different formulations of the "use" test as were appropriate to the circumstances. $^{95}$ The Privy Council's test for "use" therefore dramatically reduces the types of conduct that can be found by a Court to contravene section 36. This is because most of the predatory conduct that can be undertaken by a dominant firm can also be

91 See further RJ Ahdar "Battles in New Zealand's Deregulated Telecommunications Industry" (1995) 23 ABLR 77, 103-104.

92 See van Roy, above n 89, 56 .

93 Above n 87, 402.

94 See van Roy, above n 89 and Y van Roy "'Abuse of a Dominant Position' in New Zealand Competition Legislation" (1995) 7 ECLR 428. For a contrary view, from an Australian commentator, see W Pengilley "The Privy Council Speaks on Essential Facilities Access in New Zealand: What are the Australasian Lessons?" (1995) 3 CCLJ 26, 44.

95 This point is alluded to by van Roy, above $\mathrm{n} 89,58$. 
undertaken by a firm that falls slightly short of being dominant in the market. ${ }^{96}$ Any behaviour that a non-dominant firm in the same circumstances would have engaged in will not breach section 36 .

The restrictive nature of the Privy Council's test is clearly demonstrated by a comparison of the test with those applied by previous courts. The decision of the High Court of Australia in Queensland Wire Industries Pty Ltd $v$ BHP Co Ltd ${ }^{97}$ concerned the refusal of a dominant firm to supply a product to another firm. The High Court held that the phrase "take advantage of" was a neutral term and should not given a pejorative interpretation. Queensland Wire shows that the "use" element is not the test used to distinguish the legitimate use by a firm of its dominant position from a misuse of that dominant position. That is the function of the "purpose" element in section $36 .{ }^{98}$ This was expressly recognised by Mason CJ and Wilson J: ${ }^{99}$

[Section] 46 already contains an anti-competitive purpose element. It stipulates that an infringement may be found only where the market power is taken advantage of for a purpose proscribed in para (a), (b) or (c). It is these purpose provisions which define what uses of market power constitute misuses.

Rather, the role of the "use" element had been thought to be to provide a causal connection between the dominant firm and its conduct. ${ }^{100}$ Hampton states: ${ }^{101}$

Now it is firmly established that the "use" or "take advantage of" element does not imply any notion of misuse, attention is likely to focus on the "causation" requirement inherent in the

96 See van Roy, above $\mathrm{n} 89,58$. An example would be predatory conduct undertaken by a firm that has a "substantial market power" (The equivalent test under s 46 of the ATPA).

97 (1989) 11 ATPR 40-295. A number of Australian commentators have analysed Queensland Wire. Two useful articles are K McMahon "Refusals to Supply by Corporations with Substantial Market Power" (1994) 22 ALBR 7 and SJ Welsman "In Queensland Wire, The High Court has Provided an Elegant Backstop to 'Use' of Market Power" (1995) 2 CCLJ 280. In the later article, Welsman convincingly argues that the test in Queensland Wire is useful because it requires the court to distinguish between acceptable and unacceptable conduct when determining whether s 46 of the ATPA has been breached.

98 See the discussion by Hampton in Ahdar (ed), Competition Law and Policy in New Zealand (The Law Book Co Ltd, Sydney, 1991, 195-197 and by Y van Roy "'Abuse of a Dominant Position' in New Zealand Competition Legislation", above n 94, 435.

99 Above n 97, 50,010.

100 See van Roy, above n 89, 56-57 and the cases cited therein. See also JM November "The Meaning of 'Use' of a Dominant Position: from Queensland Wire to Electricity Corp v Geotherm Energy" (1993) 23 VUWLR 191.

101 Above n 98, 197. 
words "use that position". These words imply that there must be a connection between the impugned behaviour and the dominant position. The precise nature of this connection, however, is open to argument.

Queensland Wire established that the "use" element will be satisfied where the conduct in question was only made possible by the absence of competitive conditions. ${ }^{102}$ This was, however, only one way to establish the causal connection between the dominant firm and its conduct. The courts were prepared to adopt different tests to establish the necessary causal connection where the circumstances required it. An example is Electricity Corporation Ltd $v$ Geotherm Energy. ${ }^{103}$ This case concerned public statements by a dominant firm that it would enforce certain legal rights. These statements were intended to deter competitors from entering the relevant market. This conduct therefore occurred outside the market. The Court of Appeal held that section 36 could apply to conduct that influenced market activity, provided that "a clear and direct link between the influence and the dominant position" could be shown. ${ }^{104}$ Geotherm demonstrates that by adopting a test for "use" that was appropriate to the circumstances, the court was left with sufficient flexibility to find that the alleged conduct was a use of a dominant position. Rather than simply focusing on the "use" element, the Court of Appeal also placed significance on the "purpose" element of section $36:{ }^{105}$

The distinction between vigorous legitimate competition by a corporation with substantial market power and conduct that contravenes the section is in the purpose of the conduct.

Market power can be exercised legitimately or illegitimately.

The test adopted by the Privy Council in Telecom $v$ Clear is significantly more restrictive than the tests developed in previous cases. The Privy Council held that a firm will not use its dominant position if the firm acts in the same way as a non-dominant firm (but otherwise in the same circumstances). ${ }^{106}$ This test has been criticised because it

102 See van Roy, above n 89, 57 and FH Hanks and PLW Williams "Implications of the Decision of the High Court in Queensland Wire" (1990) 17 MULR 437.

103 [1992] 2 NZLR 641.

104 Above n 103, 649. The Queensland Wire test would not be satisfied in this situation because a nondominant firm could have made similar public statements.

105 Above $\mathrm{n} 103,649$. This is similar to the approach in Eastern Express Pty Ltd v General Newspapers Pty Ltd (1991) ATPR 41-128 and New Zealand Magic Millions Ltd v Wrightson Bloodstock Ltd [1990] 1 NZLR 731 .

106 This point has been recognised by Master Venning in Commerce Commission $v$ Southpower Limited (unreported, High Court, Christchurch Registry, 8 August 1997, CP 26/97). This was an interlocutory application concerning how the plaintiff should frame its pleadings. The Court considered the scope of s 36 in light of Telecom $v$ Clear and Port Nelson. Master Venning reached the conclusion (at pages 11-12) that s 36 "imposes a negative obligation on a dominant party not to 
exhaustively states the circumstances in which a firm does not use its dominant position. ${ }^{107}$ She argues that this eliminates the possibility of using other tests to satisfy the "use" element, as was done in Geotherm. The effect of such a narrow interpretation is that conduct which has previously been held to contravene section 36 (or section 46 of the ATPA) will now be excluded from the ambit of section 36 .

Whether a particular type of conduct satisfies the test in Telecom $v$ Clear will depend upon how the court characterises the conduct. Van Roy argues that where the conduct is defined narrowly, for instance, pricing below cost, the "use" element will not be satisfied, as both dominant and non-dominant firms can legitimately price below cost. Conversely, where the anti-competitive purpose is identified as the reason for the below cost pricing, such conduct is more likely to satisfy the "use" element of section 36, because only a dominant firm will be able to price below cost to eliminate or reduce competition. ${ }^{108}$ Characterisation issues of this nature demonstrate the difficulty, recognised in Geotherm, of analysing the "use" and "purpose" requirements separately. ${ }^{109}$

The Privy Council's decision has been further criticised on the basis that it is unprincipled to decide whether a firm has used its dominant position by assessing whether a hypothetical firm in a competitive market would behave in the same way. This argument has recently been made by Ahdar: ${ }^{110}$

With respect, [the Privy Council's] approach to causation is extremely artificial and prone to mislead. There is an air of unreality in asking how a non-dominant firm in a competitive market would have priced its essential facility. The very question strikes one as odd, as sort of an antitrust oxymoron. ...[H]ow Telecom would have acted in another setting, a competitive market (one where its source of dominance, network control, would ex hypothesi not be present), is neither knowable nor is it in issue.

The essence of Ahdar's criticism is that assessing how a non-dominant firm would behave in a competitive market is not relevant to assessing the conduct of a dominant firm in a non-contestable market. Establishing the necessary causal connection in this

use its dominance for an anti-competitive purpose. The section does not impose positive obligations."

107 A similar point is made by AI van Melle "Refusals to License Intellectual Property Rights: the Impact of RTE $v$ EC Commission (Magill) on Australian and New Zealand Competition Law" (1997) 25 ABLR 4, 27-31.

108 See van Roy, above n 89, 58. The example given by van Roy concerns a refusal to supply.

109 This difficulty was also recognised in Queensland Wire, above n 97.

110 Above n 91, 103. 
way is significantly less flexible and conceptually sound than the approach adopted in Queensland Wire.

\section{Subsequent Judicial Interpretations of Clear Communications}

The decision in Port Nelson demonstrates the restrictive effect of the Privy Council's test for the "use" element. The High Court considered whether each of the five per cent discount, the $\$ 100$ minimum charge and the tug tie breached section 36. McGechan J held that only the tug tie breached section 36. The Court of Appeal agreed with this finding although did express doubt about the usefulness of the Privy Council's test: ${ }^{111}$

While it is not easy to see why the use of a dominant position should not be determined simply as a question of fact without the need to postulate artificial scenarios, we are content in this case to adopt that approach, as did the High Court.

The Court of Appeal therefore considered whether PNL would have imposed the tug tie, assuming that competitive tug services were available to vessels in the port. Gault J concluded that a refusal to supply tugs in these circumstances would be "pointless". PNL could only refuse to supply tugs where there was no competing tug service available. Accordingly, PNL used its dominance in the tug market to affect the pilotage market. Gault J further held that a substantial purpose for PNL refusing to supply tugs was to deter or eliminate the competitive activity of TBMPL. ${ }^{112}$ The "commercial justifications" offered by PNL to explain its conduct were rejected. ${ }^{113}$ The tug tie therefore contravened section 36

The Court of Appeal did not however consider it necessary to decide whether McGechan J was correct in finding that the five per cent discount and the \$100 minimum charge did not breach section 36. ${ }^{114}$ McGechan J found that PNL's purpose in implementing each of these measures was anticompetitive. However, because a nondominant firm would have acted likewise, PNL did not use its dominant position in the wharves, tug and pilotage markets. These findings clearly demonstrate the significance

111 Above $n$ 1, 577. The similarity of this criticism to that of Ahdar's should be noted.

112 Gault J said that the "true purpose in denying tugs to ships piloted by TBMP was the fear that TBMP would secure all the pilotage work at the port and so be in a position to hold PNL to ransom." See above n 1, 578 .

113 Above n 1, 577-578.

114 The Court of Appeal did not expressly uphold MeGechan J's finding, holding that it was unnecessary to decide these issues in light of the "conclusions already reached." Despite recognising the strength of the arguments against McGechan J's findings, the Court of Appeal had "not been persuaded that the findings of the High Court should be disturbed". 
of adopting the Privy Council's restrictive test for the "use" element. ${ }^{115}$ The effectiveness of section 36 is greatly reduced. It is unfortunate that the Court of Appeal chose not to consider whether such a restrictive approach was appropriate when section 36 was being used to challenge below cost pricing and giving discounts for bundled services.

Are the courts likely to continue to apply the test in Telecom $v$ Clear? There are indications that the courts will "read down" the Privy Council's interpretation of "use". The difficulties caused by abstractly applying the Privy Council's test for "use" were recognised by McGechan J in Port Nelson: ${ }^{116}$

Reflecting the difficulty which frequently occurs in the separate analysis of s 36 "use" and "purpose" (compare Electricity Corp Ltd $v$ Geotherm Energy Ltd...) one must look at the commercial circumstances and steps taken at the time as pointing both to the course which a non-dominant firm would have taken in relation to a tie and onward to actual purpose.

Fogarty has also recognised these difficulties. He argues that both Courts in Port Nelson reverted to the test for "use" developed in Queensland Wire: ${ }^{117}$

In the High Court, use and purpose considerations were deliberately conflated in the Geotherm tradition. Post the Privy Council in Telecom $v$ Clear, the elements were kept separate in the surface logic of the Court of Appeal. But the underlying attraction of considering both elements at the same time was probably present and influential.

If Fogarty's analysis is correct, and subsequent courts approach the elements of section 36 in this way, the restrictive effect Privy Council's test will be minimised. There is already judicial support for this approach. Clear Communications Ltd $v$ Telecom Corporation of New Zealand Ltd ("Interconnection") $)^{118}$ concerned a dispute over the terms of the Interconnection Agreement entered into by Telecom and Clear in 1996. Clear alleged that Telecom breached section 36 by deactivating telephone calls made by Clear customers that did not use the 050 access code. Smellie J rejected Telecom's application to

115 If the "use" element had been seen as a causal connector, as it was in Geotherm, it is likely that the five per cent discount and minimum charge would have contravened s 36 .

116 Above n 28, 557.

117 J Fogarty "Port Nelson Follows Queensland Wire and Geotherm: Interprets AMPS-A and avoids Telecom $v$ Clear" presented at the Eight Annual Workshop of the Competition Law and Policy Institute of New Zealand Inc (Auckland, 1996) 2.

118 Unreported, High Court, Auckland Registry, 4 April 1997, CL 54/96. Compare with Purebred Jersey Breed Society (NZ) Inc v Jersey Breeders Association Inc (unreported, High Court, Hamilton Registry, 2 May 1997, CP 17/96) which applied the Privy Council's test without reading it down. 
stay the proceeding on the basis that the issues surrounding section 36's application were "both difficult and complex". 119

Smellie J also briefly considered the substantive arguments and stated a "tentative view" that Telecom had used its market dominance and that Clear's argument should prevail. These comments are significant because of the way Smellie J applied the "use" test. After quoting the test from Telecom $v$ Clear, Smellie J said: ${ }^{120}$

In deciding how such a person in that position would have acted one is required, so it seems to me, to apply the commercial reality test which their Lordships impliedly endorsed and which the High Court of Australia laid down in Queensland Wire. If that is so, then it would seem that Telecom would not have deactivated whenever possible in an openly competitive market because there would have been no advantage in doing so, indeed, a loss of revenue would have resulted. Whereas, in reality, deactivation as it is currently alleged to be happening, inevitably results in Telecom picking up the business of the consumer affected.

This demonstrates the way in which Smellie J read down the Privy Council's test in Telecom $v$ Clear in favour of the High Court's approach in Queensland Wire. Smellie J's approach therefore requires an assessment of how the dominant firm would act in a competitive market. ${ }^{121}$ This assessment, as Queensland Wire and Geotherm demonstrate, does not require the court to consider the use and purpose aspects of section 36 in isolation.

Similarly, the High Court in Clear Communications Ltd v Sky Network Television Ltd ${ }^{122}$ recently acknowledged that "bundling" similar to that undertaken in Port Nelson can still be challenged using section 36. The Court stated: ${ }^{123}$

Of course any firm would wish to secure, as available, enhanced economies of scope and scale.

It might wish to offer packages of services - "bundling" - as might any multi-product firm. It

might, in the future, undertake bundling activity, or cross-subsidisation, of a kind not open to a competitive firm... .

119 Above n 118, 11.

120 Above n 118, 12-13.

121 This is essentially the argument that was advanced by Clear. Clear argued that whether a firm used its dominant position required an assessment of whether the conduct would be engaged in by a rational and profit-seeking firm in a "completely open and competitive market". As noted above, this argument was supported by reference to Clear Communications where the Privy Council (at 403) observed that it was necessary to consider how the hypothetical seller would act in a competitive market.

122 Unreported, High Court, Wellington Registry, 1 August 1997, CP 19/96.

123 Above n 122, 63. 
This comment indicates that future courts will consider the argument that bundling of goods and services by a firm may contravene section 36 .

The appropriate approach to determining whether a firm has used its dominant position for a proscribed purpose is unclear. The Privy Council's test has attracted both judicial and academic criticism. The decisions of the New Zealand courts analysed above clearly demonstrate how the decision in Telecom $v$ Clear limits the effectiveness of section 36 as a sanction against unilateral predatory conduct.

\section{THE EFFECT OF RECENT DECISIONS ON THE SCHEME OF THE ACT}

\section{A The Relationship Between Section 27 and Section 36}

The preceding analysis demonstrates that recent decisions of the courts have fundamentally changed the scheme of the Act. The usefulness of section 36 for challenging predatory conduct has been significantly reduced by the decision in Telecom $v$ Clear. Predatory conduct that would be condemned under the broadly equivalent provisions in overseas jurisdictions is now not condemned under section 36 of the Act. ${ }^{124}$ Furthermore, much of the predatory conduct that was previously thought to be prohibited by section 36 may now not be prohibited. This result has been caused by difficulties in satisfying the high threshold necessary to establish that a firm has used its market dominance. The scope of section 36, as it relates to predatory conduct, has accordingly been reduced.

The tendency of courts to limit the scope of section 36 can be contrasted with the expansive interpretation recently given to section 27. Port Nelson clearly demonstrates that section 27 can be used to challenge predatory conduct undertaken by one firm. Collusion or concerted action is not required for a firm to contravene section $27 .{ }^{125}$ It can therefore potentially apply to the unilateral action of one firm. Conduct such as below cost pricing and offering discounts for taking a full line of services, traditionally challenged under section 36, has been held to contravene section 27.

Using section 27 to challenge predatory conduct may become increasingly attractive to New Zealand courts if such unilateral conduct cannot be successfully challenged under section 36. Eagles has recognised this possibility in a recent article: ${ }^{126}$

124 A clear example is "predatory pricing".

125 See I Eagles, above $\mathrm{n} 2$. This point was expressly stated in Clear Communications Ltd $v$ Sky Network Television Ltd, above n 122, 68.

126 I Eagles, above n 2, 466. 
Litigants are now provided with a potential means of avoiding the higher threshold under the dominance provision in any case where it is alleged that the incumbent has stolen prospective customers from an entrant by offering them enticing contractual terms in the pursuit of impure anti-competitive objectives. (It might also be added that the restrictive interpretation of use adopted by the Privy Council in Telecom Corporation of New Zealand $v$ Clear Communications Ltd is likely to propel many litigants down this particular road.)

Such an approach, however, is not without difficulty. The scheme of the Act should be considered when determining whether to apply section 27 , section 36 , or both to the particular conduct at issue. Conceptually, the unilateral conduct of a dominant firm should be challenged using section 36. This is the approach that is adopted in overseas jurisdictions which have statutory prohibitions that are similar to section $36 .{ }^{127}$ Why, then, are New Zealand courts using section 27, a section that was not originally intended to apply to unilateral conduct?

The answer to this question seems to be that section 27 is being used to "compensate" for the difficulty, perceived or otherwise, in using section 36 to challenge predatory conduct. New Zealand courts seem prepared to extend the scope of section 27 further than it has previously applied, either in New Zealand or in overseas jurisdictions. The effect of this approach is that the conceptual underpinning of each section is being blurred. Section 27, a section designed to prevent anticompetitive contracts, arrangements and understandings, is being successfully used to challenge unilateral predatory conduct. While this approach is probably preferable to allowing blatant anticompetitive conduct to escape condemnation under the Act, courts must be alert to the difficulties that adopting an approach lacking a conceptual underpinning may cause. That the courts should have regard to the statutory scheme when interpreting and applying the Act was emphasised by McGechan J in Union Shipping $v$ Port Nelson Ltd: ${ }^{128}$

[The Commerce Act] is legislation of a type where the Court should not hesitate to adopt necessary purposive approaches, in line with Northland Milk Vendors Association Inc v Northland Milk Ltd [1988] 1 NZLR 530 paying due respect to legislative policy.

While promoting competition is the overriding objective of the Act, and by definition, the objective of section 27 and section 36, a conceptually clear statutory framework should be maintained when achieving this objective. How far would the courts be

127 The narrow interpretation of s 36 can be contrasted with the expansive interpretation being given to Article 86 of the Treaty of Rome. A useful discussion of the enabling interpretation given to Article 86, in the context of predatory pricing, is N Levy "Tetra Pak II: Stretching the Limits of Article 86?" [1995] 2 ECLR 104.

128 Above n 25, 700 . 
prepared to extend section 27's application to provide a remedy to the victim of unilateral anticompetitive conduct who could not establish that the conduct breached section 36 ? The difficulty in further extending section 27's application is determining where it is appropriate to stop. There is a risk that section 36 will serve no useful function if the courts continue to interpret section 27 widely in order to prohibit conduct that should be prohibited under section 36. Such an approach is conceptually unsound and should not continue to be perpetuated by the courts.

\section{CONCLUSION}

The decision in Port Nelson is significant because it demonstrates the courts' willingness to ensure the promotion of competition in New Zealand markets. The five per cent discount and the below cost pricing were successfully challenged under section 27. PNL's refusal to supply tugs was successfully challenged under section 36 . How each section was interpreted and applied in Port Nelson is significant not only for the outcome of the case, but also for the likely outcome of future cases where similar conduct is being considered.

The Court of Appeal significantly widened the scope of section 27 by affirming McGechan J's finding that the section applies where only one party to a contract has an anticompetitive purpose. Section 27 can now be used to challenge unilateral conduct. This finding is difficult to justify when one considers that the policy underlying section 27 requires the contracting parties to collude to achieve an anticompetitive result before the section applies. Whether future courts will apply section 27 in this way remains to be determined.

Port Nelson was the Court of Appeal's first opportunity to consider the Privy Council's judgment in Telecom $v$ Clear. While the Court did express dissatisfaction with their Lordships' interpretation of the "use" element of section 36, it did not attempt to limit the application of Telecom $v$ Clear in future cases. The result is that section 36's effectiveness in challenging predatory conduct is greatly reduced. Although there are indications that future courts may have regard to the reasoning in cases like Queensland Wire and Geotherm, this result is far from ideal.

Port Nelson is also significant for other reasons. Both section 27 and section 36 were closely analysed. The scope of section 27 has been usefully clarified. The Court of Appeal emphasised the importance of the distinction between lessening competition and lessening the effectiveness of an individual competitor. Furthermore, the Court clarified the relationship between the purpose, effect and likely effect limbs of section 27 . This analysis will no doubt assist future courts when applying the Act.

The argument made in this paper is that the approach of both Courts in Port Nelson fails to have sufficient regard to the scheme underlying the Act. Section 27 should target 
collusive anticompetitive conduct. Section 36 should target the anticompetitive conduct of dominant firms. The decision in Port Nelson has fundamentally changed the scheme of the Act. It is questionable whether the court should interpret the Commerce Act in this way. 